\title{
Obraz kobiety w staropolskich popularnych poradnikach medycznych
}

Alicja Zdziechiewicz 
nAPNS Seria IX 2(0)( 3

Alicja Zdziechiewicz

\section{Obraz kobiety w staropolskich popularnych poradnikach medycznych}

W dotychczas napisanej historii medycyny brakıje pierwiastka kobiecego. Nie chodzi tutaj o nagle odkryte pisma wybitnych lekarek — aczkolwiek mieliśmy w XVIII wieku okulistkę, która przez kilka lat spełniała funkcję nadwornego lekarza haremu sultańskiego: Salomę̨ Rusiecką, z powodzeniem przeprowadzającą operacje zaćmy — ale o zastępy „lekarek", o których opracowania z zakresu historii kultury mają dotąd niewiele do powiedzenia. To one przede wszystkim były odbiorcami poradników medycznych. Z tych zaś z kolei wyłania się nieco inny niż powszechnie znany obraz kobiety.

Trzy części niniejszego artykułu skupiają się na sferach umyshı, ciała i domu. W kazdej opisano dzieła, które wspomagały rozwój kobiet pod wymienionymi względami i zaspokajały ich potrzeby. Zobaczymy, jak kobiety miały możliwość dbania o siebie i innych. Pominięta została sfera duchowości, gdyż poradıiki, jako książki użytkowe, zasadniczo nie zajmowały się tą kwestią, najwyzej ich autorzy pozwalali sobic niekiedy na komentarze natury moralnej, ozdabiając je nielicznymi egzemplami i opowiadaniami!

Zajmiemy się dziełami powstalymi w XVI i XVII stuleciu oraz w pierwszej polowie XVIII wieku, w języku polskim, gdyż reprezentıją pewien sposób myślenia, który dość radykalnie zmieni się w czasach Oświecenia; zatem nasze rozważania zamkniemy na dziele, które powstało w 1715 roku. W okresie staropolskim poradniki medyczne bywaly niejednokrotnie jedynym źródlem wiedzy na temat zdrowia. Istniały wprawdzie dzieła medyczne, w renesansie głównie wydania starożytnych twórców w języku łacińskim, przeznaczone dla lekarzy-praktyków i dla potrzeb uniwersytetów. Jednakże już w XVI wieku zdawano sobie sprawę z niedo-

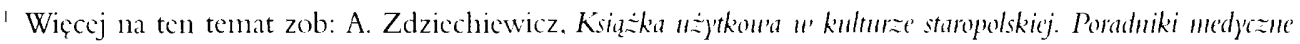
(w przygotowaniu). 
statecznej ilości lekarzy i aptek. Świadomość ta zbiegła się z renesansowym humanizmem, który postulowal przyjazną troskę o ludzkie ciało, bogacenie się miast i troskę o popularyzację wiedzy związanej ze sprawami doczesnymi.

Pojawia siç pytanie, dlaczego popularne poradniki medyczne wieku XVI nie zostały spisane po łacinie, w języku uczonych? Można przypuszczać, że czasy renesansu sprzyjały rozwojowi języków narodowych, ale istnieją przecież dzieła napisane po łacinie przez polskich lekarzy. Pisano po łacinie, by chronić wiedzę przed profanami? Poradniki medyczne musialy zatem być przeznaczone dla innego rodzaju odbiorcy niż medycy — dla ludzi nieposiadających wyższego wykształcenia. Jednocześnie należy szukać też innych przyczyn, dla których poradniki te pisano po polsku, bo przecież przyszli użytkownicy poradników - synowie szlacheccy - uczyli się wówczas łaciny w szkołach.

Interesować nas będą tutaj najpopularniejsze dziela medycznego piśmiennictwa staropolskiego: ziehniki². a także kompendia wiedzy medycznej ${ }^{3}$.

Dzieła te dedykowane były lekarzom, aptekarzom, cyrulikom, ówczesnym weterynarzom, gospodarzom, a wreszcie paniom. Slowo „pani” było tytulem grzecznościowym, ale nie obdarzano nim każdej kobiety. Mówiono w ten sposób o szlachciankach, arystokratkach, czasem o żonach bogatych mieszczan, którzy wchodzili w koligacje rodzinne ze zubożała

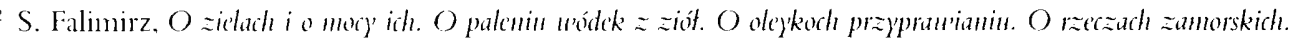

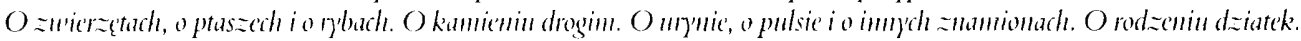

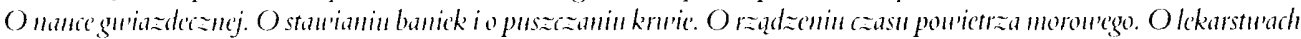

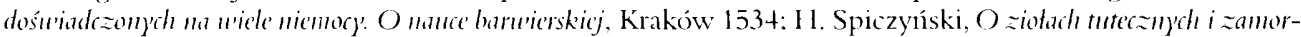

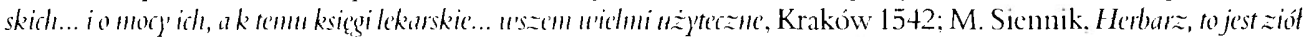

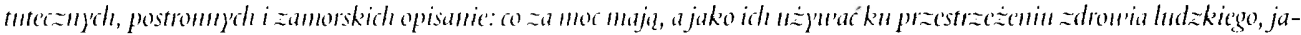

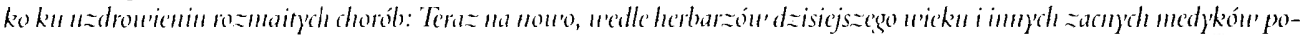

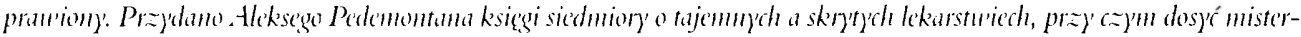

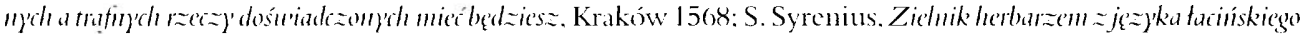

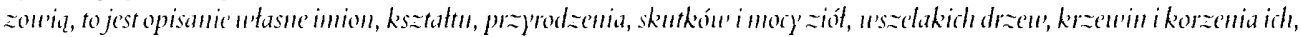

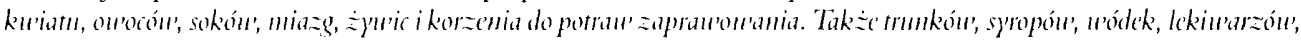

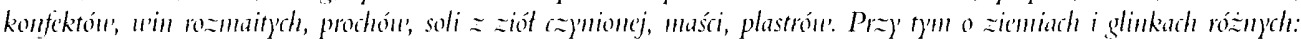

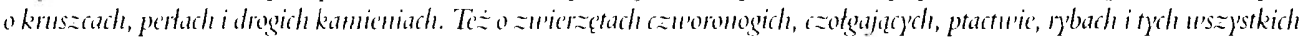

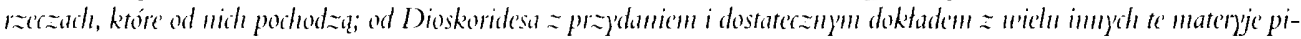

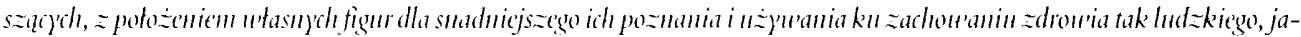

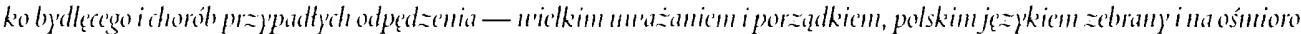

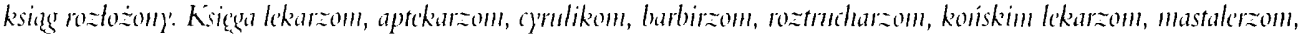

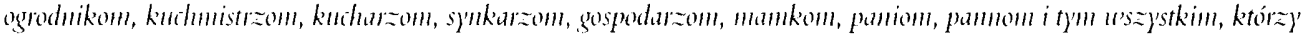

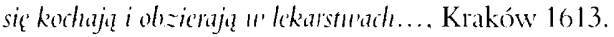

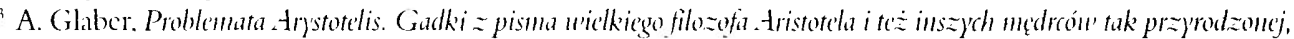

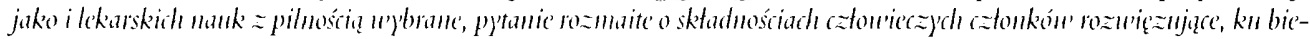

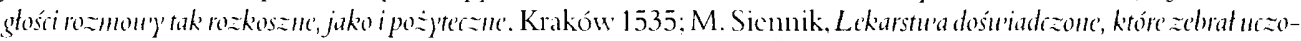

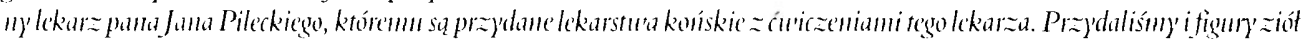

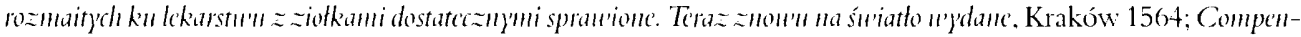

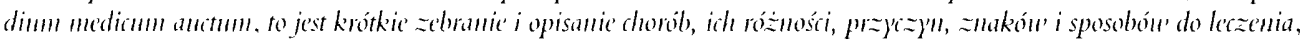
Częstochowa 1715; A. Pedemontan. przedmowa do: Tajemmice usz)stkim obojga ptri nie t) tko ku leczemin nazmai-

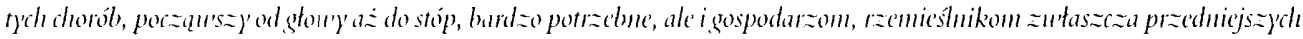

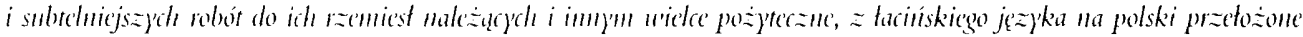

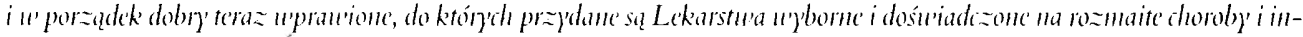
szych recey w'iele. tl. S. Sleszkowski, Supraśl 1732. 
szlachtą, aby przejść o jeden szczebel wyżej w drabinie spolecznej. Skıpimy się na tym wlaśnie typie kobiety.

Pani domu odpowied zialna była za wiele spraw, związanych z gospodarstwem, to ona nim zarządzała, dbając o rodzinę. Jeśli cieszyla się zaufaniem męża, miała w domu sporą władzę nad słuzbą i resztą domowników. Mimo że tradycyjnic odmawiano jej wyksztalcenia szkolnego, mogła uzupełniać je we własnym zakresie. Większość kobiet zainteresowanych podniesieniem swego stanu wiedzy tak czynila, czy to poprzez wybór stanu (klasztor umożliwiał naukę), czy też lcktury. Panny „z dobrych domów” przechodziły edukację, która miała z nich uczynić dobre żony, a jednocześnie zarząd czynie domostwa. Dotyczylo to również, jak się niżej okaże, utrzymywania domowników w dobrym zdrowiu.

\section{Umysł}

Dzieł napisanych specjahnie dla kobiet w interesującym nas okresie powstalo niewiele. Dotyczy to również poradników medycznych. W XVI wieku powstał najprawdopodobniej tylko jeden traktat, mający na celu popularyzowanie wiedzy medycznej i paranedycznej wśród niewiast. Dziełem tym są Problemata Anjstotelis. Godki z pisma unelkiego filozofa Aristotela i tez in-

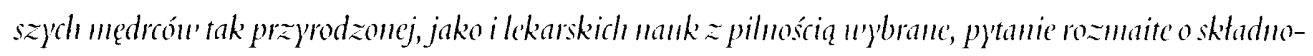

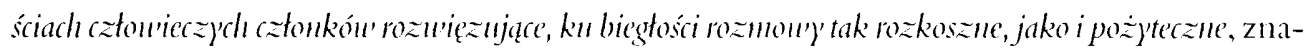
ne również jako Gadki o sktadności cztonkón' czlon'ieczy'ch, wydane w Krakowie w roku 1535.

Mistrz Andrzej Glaber z Kobylina wykładat na Akademii Krakowskiej filozofię Arystotelesa, astronomię, astrologię i teorię planet ${ }^{\dagger}$. Mógł to czynić już po ukończeniu wydziału sztuk wyzwolonych, podobnie jak Marcin z Urzędowa, który wykładał jeszcze przed swoim wyjazdem po doktorat do Włoch. Świadczy o tym między innymi zredagowany i wydany w roku 1539 przez Glabera skrypt w języku łacińskim dla studentów triı́um, łączący w sobie kompendia z zakresu gramatyki, retoryki i dialektyki ${ }^{5}$. Wykładając zatem „naukę gwiazdeczną” oraz elementy filozofii Arystotelesa, mial dostęp do lacińskich Problematóu' Arystotelesou')'ch. które cieszyły się wówczas wielką popularnością na uczelniach. Problemata nie sąjednak oryginalnym dziełem tego filozofa. Zarówno lacińskic, jak i polskie wydania są kompilacją elementów fizjognomiki Arystotelesa, poglądów I Iipokratesa, Galena, Pliniusza, Seneki, Awicenny, Konstantyna, Izydora, Alberta Wielkiego, Ebehardusa i innych średniowiecznych myślicieli".

\footnotetext{
+ Podajç za: W. Wąsik. Andrzcj Glaber z Kolyylina problematysta polski. Warszawa 1916, s. 19.

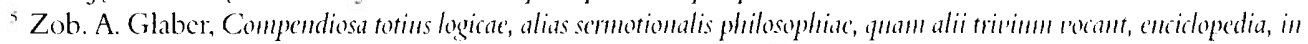
modum Enthiridii apposite redacta. Cracoviac 1539. Zwraca uwagę fakt druku owej ksiazzeczki w oficynic Unglera, która wydala dwa picrwsze ziclniki Falimirza i Spiczyńskiego.

"Mial to być zbiór ..podróbek z podróbck, skrót ze skrótów. drogą okólną poprzez medium syryjskiego, arabskicgo i hebrajskiego języków. (...) drugi konicc już skręconcj nici zostaje podany średniowiceznym autorom, którzy poczęli go skręcać i rozkręcać na swoją modlę. zgodnic z tendencjami kościclnymi i moralizatorskimi swcj cpoki" (W. Wąsik, op. cit., s.t5; zob. też s. 36-77).
} 
Glaber usunął z łacińskiej wersji calą uczoność, czyniąc polskie Gadki... dziełem popularnonaukowym, przybliżając go prostej, niewykształconej czytelniczce, jak sam stwierdzil, w celu wzbogacania sztuki konwersacji. Tłumacz ten oswoił Problemata do tego stopnia, ze pewne argumenty popieral dowodami z historii Polski, pisal o naszym klimacie, Tatarach, Litwinach, Polakach, dostosowując swoją wersję do potrzeb polskiego odbiorcy. Był to w zasadzie pierwszy nasz popularny wykład fizjologii, higieny i fizjognomiki, który mógl spełniać rolę Szkót Salemitańskich ${ }^{7}$ na naszym gruncie, w dodatku podając przyczyny chorób i zjawisk fizjologicznych, a nic tylko wierszowany przepis na zdrowy tryb życia. Moim zdaniem Glaber stawia swoim odbiorcom większe wymagania niż autorzy ze szkoły w Salerno - wymaga myślenia, a nie tylko pamięciowego opanowania tekstı.

Już przedmowa zaskakuje czytelnika. Biorąc pod uwagę, jak bardzo kobiety były potępiane przez duchowieństwo za swoją naturę, charakter, cielesność, gdy czyta się Młot na czarouniae, chyba najbardziej antykobiecy tekst clurześcijaniski, i wybrane myśli ojców Kościola ${ }^{\gamma}$, słowa Glabera, mówiące o zazdrości mężczyzn w stosunku do kobiet, robią wrażenie nawet dzisiaj.

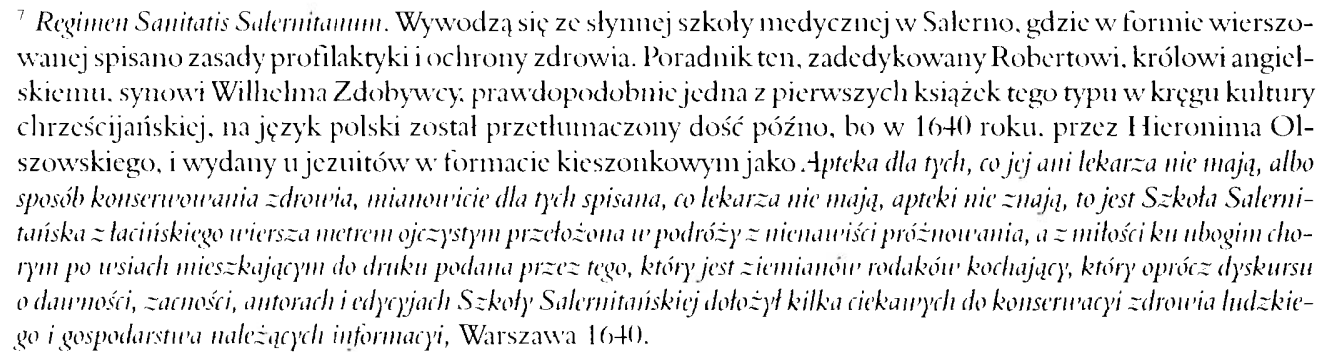

* Nicmiecki teolog z XI wicku, Andreas Capellanus: ..Zgodnic ze swą naturą (...) każda kobieta jest urodzonym skappeem (...). jest tez zawistna i chętuic obmawia inne kobicty. jest chciwa. jest niewolnikiem swego zolądka. jest nie postuszna i nie znosi ograniczeń, jest napiętnowana grzechem pychy (...), jej przywary to kłamstwo, pijaństwo, gadulstwo: nic potrafi utrzymać w tajemnicy powicrzonego jej sekretu; lubi kaprysić, jest podatna na w'szelkic zlo i nigdy nic kocha mężczyzny w glçbi swego screa" (cyt. za: F. Becr. Koblict)' i dośuriadczenic mistyrent' u'średniourieczl, tl. A. Branny. Kraków 1996, s. 33). Andreas Capellanus wzoruje się w tcj charakterystyce na Ojcach Kościola: .. Opinic Jana Cluryzostoma - «Wzystko zepsuła kobicta... Pleć zeńska jest staba i nicstała... Caly zeński ród zgrzesszyl” są w gruncic rzeczy echem pytania Tertuliana: «Czy zapomnialaś, ze jesteś Ewą? Boski wyrok wciąz nad tobą wisi. boska kara nadal nad tobą ciąży”" (Beer, op. cit., s. 3t). Tertulian pisal także: ..Winnaś zawsze nosić żalobę, byé okryta lachmanani i ogarniçta skruchą, by odkupić grzech zgubicnia rodzaju ludzkicgo (...) Kobic to, jesteś hramą diabla. Ty dotknç̣laśdrzewa szatana i ry pierwsza pogwalcilaś prawo Boskic" (cyt. za: J. Dcluncaut. Strach we kulturze Zadhodu, tl. A. Szymanowski, Warszawa 1986. s. 292). Klcmens Alcksandryjski (zm. przed 215 r. n. c.) mapisal, że w kobiccic ,juz sama świadomość wasncj istoty musi wywolywá poczucic wstydu. (...) Poza swoim donem kobicta powinna calkowicie się zakrywać. Przez to. że zakryje swą twarz, nikogo nie przywicdzie do upadku" (cyt. za: U. Ranke-Heineman, Eumuch' do raju, tl. M. Zcller. Gdýnia 1995. s. 131). Jeden z najwiçkszych Ojców Kościola. św. Augustyn, napisal w dziele De Ge'nesi ad litteram (401-+15): .Nie wiem, do jakicj pomocy mężczyźnic zostala stworzona kobicta.jeśli wykluczymy cel prokreacji. Dlaczego mimo to cel ten siç wyklucza, nie rozumiem. Jeśli kobicta nic zostala dana mężczyźnic do pomocy w rodzeniu dzicci. w takim razic do czego? Może do tego, by razem uprawiali ziemię? W takim razic lepszą ponocą dla mężczyzny bylby mężczyzna. To samo tyczy się pociechy w samotności. O ileż przyjemnicjsze jest życie i rozmowa, gdy mieszkają razem dwaj przyjacicke, niż mężczyzna i kobicta" (cyt. za: ibidem, s. 91). Deket Gracjana (ok. 11+()-1150), który, wedlug Delumeau, byl jeszcze do początkuXX wicku ghównym źródlem prawa kościchnego, zawiera stwierdzenic: „Ten obraz Boga jest w mężczyźnie [Adam]. stworzonym jako jedyny. jako źródto wszystkich imnych istot ludzkich, otrzymał bowiem od Boga 
Andrzej z Kobylina, posługując się twierdzeniem Arystotelesa, że im subtelniejsze ciało, tym umysl wybitniejszy, przyznaje, że dziewczynki mają większą skłonność do nauki niż chłopcy:

Bacząc tedy mężowie skladność płci panieńskiej, iż jest bardzo subtylna, a rozum ich ku natıce i wyrozumieniu wszelkiej rzeczy ostry a prędki, więcej niż otroczy" (jakoż się to jawno ukazuje w dziatkach z młodu, gdyż dzieweczki rychlej się imują mówić niźli chlopeczkowie, to wszystko sprawuje przyczyna przyrzeczona), przeto oni, bojąc się swojéj sławy utracić, aby biale glowy rozumem ich nie przechodzily, chcąc wiele umieć, bronią im czytania pisma głębokiego, chyba modlitw a paciorków. Wszakoż mądremu rozumowi nie zda się to rzecz shuszna, aby dla jednej niewiasty abo dwu (które mądrości źle pożywając, ku złemu ją obracają) jużby więc wszystkic mialy stradać dobra, od Boga człowieku danego. Gdyż Pan Bóg nie chcial tylko samych otroków na świecie mieć, ale jak skoro Adama stworzył, tudzież dal mu towarzyszkę, we wszystkim temu podobną, i owszem, z rzeczy subtylniejszej stworzona, bowiem z kości białej, gdyż mąż ulepion jest z ziemi grubej. Przeczże one niebogi mają być tak wzgardzone, a podlejsze niźli mężowie? ${ }^{10}$

Glaber dowodzi swego twierdzenia, powołując się na przyklady pań rzymskich, które były mądre, bo pozwolono im się uczyć, a także na polską królewnę, Wandę, którą panowie polscy wybrali na królową ze względu na jej stateczność i mądrość. Zastanawiający jest fakt tak żarliwej obrony niewiast w świecie patriarchalnym. Można by sądzić, że tlumacz uciekł się do podstępu, chcąc wyjednać protektorat dla swojego dzicła u kasztelanki żarnowskiej, Hedwigi z Kościelca, pani Oświęcimia, Czechowic i Zatora, której swą pracę ofiarowat.

Która wykształcona i bogata kobieta, widząc takie słowa na papierze, nie pokusi się o to, by je rozpropagować? Dzielo to jest zadedykowane bezpośrednio kobietom, zatem Glaber pewnie spodziewal się, że zakıpiąje panie dbające o swoją edukację. Wspomina on w przedmowie jednakże i o tym, że stara się o wydanie żywotów wielkich Polek

whadzę rządzenia jako Jego zastępca, gdyż jest wizerunkicm jedynego Boga. Dlatego też kobicta nic została uczyniona na obraz Boga" (Delumeau. op. cit., s. 293). Późnicj. gdy chrzéśijanie odkryli dla sicbic Arystotelesa, przyswoili też jego poglądy na temat kobict. Filozof ten uważal, że to mężczyzna jest daweą życia podezas zaplodnicnia, a kobicta to tylko jakby glinianc naczynic, poślednia materia w procesic reprodukcji: rolą mężczyzny jest dostarczenic bezcennej formy. pierwiastka ruclun. Tak wiçc odebrana zostala kobiccic rola dawezyni zycia, jej rola zostala ograniczona do funk cji brzucha. który nosi i karmi plód w czasie ciązy. Delumeau interpretuje to jako istnienie tylko jednej płci: męskicj. natomiast nicwiasta staje siç przez to nicpehnym mężczyzną. Kobicta z racji swojego upośledzenia nic ma prawa decydować o sobic. Św. Tomasz z Akwinu w związku z tym napisze: „Kobicta potrzebuje mężczyzny nic tylko po to, by plodzić, jak to jest u innych zwicrząt, ale nawet. by rządzić sobą: gdyż sanniec jest doskonalszy przez swój roztum i silnicjszy w cnocic” (ibidem, s. 294).

"Stp: chlopiçcy.

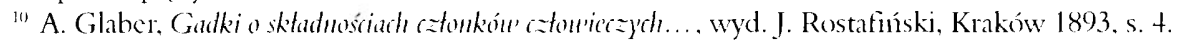


...za laską Bożą, (...) ku pociesze i kı pobudzeniu na cuoty dobre paniam, które swą sprawą chcą po sobie dobrą sławę zostawić"

Zamiar chwalebny, ale najwidoczniej nie powiódl się, gdyż Glaber nie wydał takiego dzieła. Udało się jednak wydać Gadki o składnościach członkóu' człon'ieczych, pierwszy polski poradnik inedyczno-filozoficzny, i prawdopodobnie w ogóle pierwszy nasz tekst popularnonaukowy, skierowany do kobiet.

Część pierwsza Gadek, Problemata Arystoteleson'e, zbudowana jest na zasadzie katechizmu: pytań i odpowiedzi, które mają pomóc czytelniczce w zrozumieniu skomplikowanej budowy świata i celowości dzialaı́ Bożych. Przyktadem może być pytanie o przyczynę wyprostowanej sylwetki człowieka i twarzy w górę wzıliesionej. Odpowiedź jest prosta — po pierwsze: ze zrządzenia Bożego (w ten sposób tłumaczona jest większość wątpliwych kwestii), po drugie, aby, patrząc ku niebu, człowiek gardzil rzeczami przyziemnymi ${ }^{12}$.

Pojawia się tu również wszechobecna w poradnikach teoria czterech żywiołów i „humorów" (płynów) w ludzkim ciele, wedle której autor thumaczy wiele zachodzących w człowieku zjawisk i procesów fizjologicznych, a także objaśnia ich przyczyny wedlug zasad mitologiki. Śledziona jest czama. bo jest z „materyjej ziemskiej”, która ma ten kolor ${ }^{13}$. Oczy czarne lepiej widzą w dzicń niż w nocy -

To bywa dla niedostatku ognia, któryby mógł mocniej wilgość lodowatą oświecać, jako bywa w oczı kotowych abo inszej zwierzyıy ${ }^{1+}$.

W wiçkszości kwestii pojawiają się argumenty wywodzące się z empirii. Dla przykladı: kobiety mają dłuższe włosy niż mężczyźni, bo są wilgotnicjszej natury niż oni, a włosy do wzrostu potrzebują flegny; poza tym kobietom nie rośnic broda, bo wszystko mnoży im się na głowie $^{15}$. Długie, rozpuszczone włosy w wielı wypadkach kojarzono z diabłem w nich obecnym. Wywodziło się to jeszcze z dawnej wiary, że takie włosy nosily demony wodne ${ }^{t h}$. Później takie właściwości przypisywano w kulturze chrześcijańskiej włosom kobiecym, zwłaszcza czarownicom. Tak więc próba wyjaśnienia obfitości włosów u kobiet przyczynami naturalnymi świadczy o racjonalnym podejściu autora do zagadnienia. Równiez problem owlosienia twarzy kobiet w wieku menopauzalnym Glaberowi udaje się wytlumaczyć rozumowo (nawet przed odkryciem hormonów), uzasadniając go zmianami w organizmie po zaniku menstruacji.

Racjonalizm i zdrowy rozsądek jest charakterystyczny dla tego dzieła, które realizuje tę koncepcję thumaczenia świata od początku do końca. Żadne z pytań nie pozostaje bez odpo-

1 Ibidenn.

12 Zob. ibidem, s. 16 .

${ }^{13}$ Ibidem, s. $5 t$

it Ibidem. s. 19.

15 Zob. ibidem. s. II.

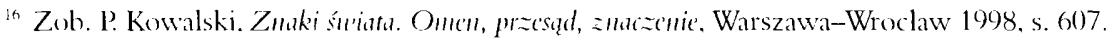


wiedzi, co świadczy o wielkim zaufaniu Glabera i tych, którzy w ciągu wieków komponowali Problemata, do ludzkiego rozumu.

Autor próbuje znaleźć przyczynç i cel każdej rzeczy, na przyklad: kobiety mają „cyce na piersiach", a nie na brzuchu jak inne samice, bo przeszkadzalyby im w chodzeniu" ${ }^{17}$; ptak nie posiada uszu, gdyż przeszkadzalyby mu w lataniu, ale znowu człowiek ma dwoje uszu i jedıe usta, bo powinien po dwakroć więcej słuchać niz mówić ${ }^{1 \times}$. Uderza tutaj wspólistnienie moralizatorstwa w przypadku człowieka i prostego myślenia w przypadku świata zwierzęcego, w czym - w rozımieniu autora — objawia się wyższość pierwszego nad drugim.

Nie brakuje również argumentów teologicznych, które sprawiają, że Gadki zbliżają się momentami do traktatu scholastycznego. Z drugicj strony pojawiają się echa renesansowej koncepcji przyrody, gdy przywołane zostają slowa, że „Bóg i natura niczego nie czynią próżno" "1".

Problemata zbudowane są z trzech części:

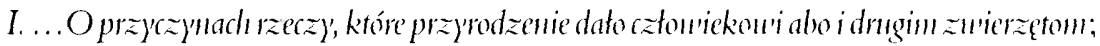

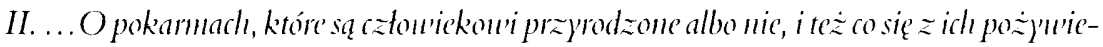
nia cztou'icku przydaw'a;

III. Co który' sposób albo postan'a catonkón' czlourieczy'ch zmamionuje, jestli dobroć abo zóté prz)'rodzona $a^{211}$.

Część pierwsza to kurs anatomii człowieka, od glowy począwszy, przez piersi, paznokcie, płuca i wątrobę, na nogach skończywszy. Anatomia ta zdaje się być pretekstem do rozważaí na temat natury kazdej rzeczy. W rozdziale o głowie padają na przykład pytania o naturę włosów, dlaczego kobiety mają ich więcej i delikatniejszej struktury niż mężczyźni, o przyczyny łysienia mężczyzn (mają w sobie za wiele gorąca, które powoduje wypadanie włosów), dlaczego tysi są chytrzy (bo są cholerykami), czemu na ogół niewiastom broda i wąsy nie rosną, a "starym żonom” się to przytrafia ${ }^{21}$.

Gadki zawierają również przesądy na temat kobiet, jakim ulegano w XVI wieku i wcześniej. Jednym z wierzeń, utrzymującym się w kulturze od czasów starożytnych, jest przekonanie, że kobiety w czasie miesiączki psują nowe lustra, „bo im jady uciekają przez oczy”22. Lustro, które wedlug tradycji myślenia magicznego jest bramą zaświatów, ponieważ świat widziany $w$ nim jest odwrotny do ziemskiego ${ }^{23}$, mętnieje pod wpływem spojrzenia kobiety, również znajdującej się w fazie śmierci - przed odrodzeniem w czasie owulacji, przywrócenia mocy witalnych i płodności. Lustro psuje się, gdyż oczy kobiety zmieniają się wraz z jej statusem. Będące pod wpływem Księżyca ciało kobiece przechodzi fazy podobnie jak on.

7 Zob. A. Glaber, op. cit., s. 43.

is Zob. ibidem, s. 24.

${ }^{14}$ Ibidem, s. $12 t$.

20. Ibidem, s. 6.

21 Ibidem, s. 11-13.

I2 Ibidem, s. 19.

23 Zob. 1. Kowalski, op. cit., s. 289. 
Owulacja jest pełnią, menstruacja - brakiem, cykliczną śmiercią. Oczy w tym okresie mają moc destrukcyjną, gdyż kobieta jest istotą w stanie przejściowym - między życiem a śmier$\mathrm{cią}^{2+}$. O „nieczystej naturze” miesiączkującej kobiety pisali już autorzy biblijni, nakazujący miesiączkującej kobiecie mieszkać poza obozem ${ }^{25}$. Do dzisiaj wiara w jej niszcząca moc przetrwała w tradycji europejskicj, a krew miesięczną, jako ściśle związaną z ciałem, mającą moc przywiązywania, bardzo dlugo uważano za jeden z najpotężniejszych środków magicznych, używanych zwłaszcza w czarach miłosnych ${ }^{20}$. Do dziś zresztą pozostał szereg przesądów na temat miesiączki: nie należy w tym czasie robić sobie trwałej ondulacji, gdyż włosy się źle skręcą albo wcale, z ciasta zrobi się zakalec, nie uda się ubić piany z białek ${ }^{27}$.

Elementy fizjognomiki Arystotelesa nie zostały umieszczone w Gadkach przypadkowo ani dla rozrywki, czy też wiedzy samej dla siebie. Glaber proponuje praktyczne korzystanie z porad zawartych w jego dziele: „aby każdy mógł wiedzieć, z kim ma towarzyszyć albo kogo się chronić"28.

Charakter człowieka można odczytać z twarzy niczym horoskop z gwiazd. Zestawienie to nie jest przypadkowe. Ówcześni ludzie wierzyli, że przy pomocy wiedzy astrologicznej można przepowiedzieć charakter i dalszą drogę życia, z jej radościami i zagrożeniami. Kościół nie uznawal wtedy takich prób poznawania przyszłości za grzech, gdyż uważano, że po to Bóg obdarzył czlowieka rozumem, by ten umiał odczytać Boskie przestrogi w Jego tworach. Idąc dalej tym tropem, ponieważ natura niczego nie czyni na próżno, ludzka fizjonomia musi mieć jeszcze inne znaczenie niż tylko wyróżnianie jednostki z thumu i podobieństwo do rodziców. Charakter czlowieka można poznać po znamionach, jakimi są wzrost, kolor i gęstość wlosów i brwi, budowa ciala, wielkość i kształt glowy, wyraz twarzy, czoła, kolor i osadzenie oczu, wielkość nosa, warg, zębów, a nawet języka.

Tak oto głowa wielka i okraggla

...znamionuje czlowieka rozumnego, dowcipnego i w sprawach wszystkich dobrze bacznego, robotnego też, stałego i pobożnego. Nie wierzyszli, oglądaj ${ }^{29}$.

Głowa mała, z miękkim gardłem i pochyloną szyją, wskazuje na człowieka spokojnego, cichego, tajemniczego i skąpego w uczynkach. Głowa podługowata, z długą twarzą znamio-

${ }^{24}$ Zob. ibidem. s. 314.

${ }^{25}$ Kpł 15, 19: ..Niewiasta, która co miesiąc cicrpi plynicnic krwic, przez siednn dni będzic odlączona” (tl. J. Wujck).

26 Zob. E. Karwot, Katalog magii Rudolfa. Źrólto ctmograficzme z.XIII uickn, Wrocław 1955: umieszczony jako

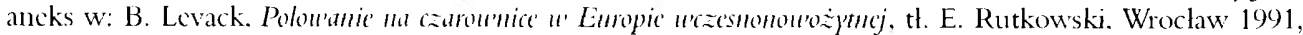
s. $285-29()$.

${ }^{27}$ Zaslyszanc (200)1 r.).

${ }^{2 x}$ A. Glaber, op. cit., s. 126. Argument ten przywolywany byl jeszcze w I polowie XX wicku w jarmarcznych

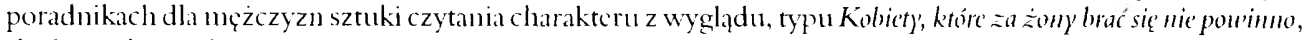
skąd wynika. że do zamążpójścia nie nadaje siç polowa kobict, ake nic warto nad tym plakać, gdyż ich i tak na świecie jest ich za dużo.

24 Ibidem. s. 133. 
nuje prostaka, głupiego, złośliwca, zawistnego, próżnego i plotkarza. Kto głową prędko rusza, sam jest plotkarzem, kłamcą niestatecznym. Znowu człowiek, którego głowa

...miąższa a strojna z miąższą a krótką szyją ukazuje czlowieka dobrze bacznego, mądrego, rozumu dobrego, tajemnice chowającego, wiernego, prawdziwego i bardzo powolnego ${ }^{31 !}$.

Glaber ukazuje wygląd ludzi, których należy się strzec ze względı na ich wady:

Twarz, która się zda jakoby pijana, ukazuje mocnego, próżnomówcę, psotliwego, który się też rad napija, wszakoż nikomu nie zaszkodzi, tylko g̨̨bą ${ }^{3 !}$.

Czoło gładkie, bez zmarszczek znaczy człowieka gniewnego, falszerza i plotkarza ${ }^{32}$; rzadkie brwi charakteryzują tatwowiernego prostaka ${ }^{33}$; oczy glęboko osadzone należą do osoby ostrego wzroku i dobrej pamięci, lecz przewrotnej, złośliwej, zawziętej, podejrzliwej, zwodzącej ku zlemu i pysznej ${ }^{34}$; wargi blade oznaczają proste obyczaje, .zęby miąższe” a szerokie wskazują charakter waleczny, kłamliwy, obłudny, mocny i głupi ${ }^{3.5}$.

Do czego służył poradnik Glabera? Sądzę, że część pierwsza i druga pomagały w pozmaniu funkcjonowania ludzkiego ciała i stanowiły uproszczoną wersję naukowego podręcznika. Kobiety zaznajomione $z$ anatomią, fizjologią i dietetyką, na poziomie, który według Glabera z pewnością im wystarczyl, miały podstawową wiedzę do wykorzystania w domowej praktyce. Fizjognomika natomiast dostarczała wiedzy nie tylko praktycznej, ponieważ pozwalała na wzbogacenie tematów rozmów, dzięki czemu kobiety mogły próbować dorównać poziomem amysłowym wykształconym rozmówcom. Poradnik ten podnosi status kobiety w towarzystwie, ukazując, że może ona być interesıjącym partnerem w konwersacji i że możliwa jest rozmowa wykraczająca poza teren „modlitw a paciorków” oraz problemów domowych, tradycyjnie przypisany niewiastom.

\section{Ciało}

Najciekawsze i dostarczające najwięcej materiału obyczajowego, w którym ukazany jest portret kobiety dawnych czasów, są poradnikowe recepty kosmetyczne, z których dowiadıjemy się międ zy innymi, jakie obowiązywały dawniej kanony kobiecego piękna, a także jak dbano o urodę.

Charakterystyczna jest przewaga poradników dotyczįcych ciala w stosunku do umyslu, co świadczy o większym zainteresowaniu kobiet własną cielesnością.

\footnotetext{
${ }^{310}$ Loc. cit.

"Ibiden. s. 137.

3. Zub. ibidem, s. 1+0)

${ }^{33}$ Zob. ibidem, s. $1+2$

${ }^{34}$ Zob. ibidem, s. $1+7$.

${ }^{15}$ Zob. ibidem, s. 149 .
} 
Poradniki przynoszą obraz pachnącej kobiety o bujnych, dhugich włosach, małych piersiach, delikatnej, nieskizitelnie białej cerze, ale z rumieńcem, a także z bardzo wysokim czołem, o bezrzęsnych oczach i bialych zębach. Portret ten wyłania się z Tajemmic Aleksego Pedemontana, niezwykle poczytnego wloskiego dzieła, które przyjęło się także na naszym gruncie $^{36}$.

Co ciekawe, ukazuje on ideal kobiety bardziej „czasów katedr” niż późnego renesansu włoskiego, o czym świadczą pochwaly powiek bez rzęs, bardzo wysokiego czoła, wymagającego depilacji, i być może drobnych piersi. Zatem przepisy kosmetyczne, znajdujące się w receptularzu Aleksego z Piemontu, powstaly zapewne nieco wcześniej, niż się powszechnie sądzi... Bujne włosy zawsze byly oznaką kobiecości, więc trudno mówić o nich jako o znaku przynależności czasowej kanonu; podobnie było przecież z białą cerą aż do wiekuXX.

Dążenie do idealu wymagalo wiele wysiłku, dlatego znaczną ilość miejsca w poradnikach zajmują recepty na kosmetyki. Książa Pedemontana, podobnie jak Lekarstw'a doświadczone Siennika, zaczyna się nawet nie od omówienia leków na choroby głowy (inaczej niż można by przypuszczać, wiedząc, jak układane byly wszystkie kompendia medyczne), lecz przepisami na farbowanie i trefienie włosów, co, jak mi się zdaje, jest argumentem potwierdzającym tezę, iz receptularze te powstały na zamówienie kobiet. Wlosy barwiono na trzy kolory: czarny, blond (zólty) i rudy (czerwony). Przykładowo, aby włosy uczernić,

...weźmi zielonych jaszczurek a oberżnij im ogony i glowy, warz je w oliwie, a tym olejkiem whosy pomazuj, będą się czernialy i dhugie rosty ${ }^{37}$.

Siennik, również na początku rozdziału o chorobach głowy ze swoich Lekarstu' dośuiadczonych, podaje przepis na czarną farbę do whosów:

${ }^{36}$ Niezwykla książka Alekscgo Pedemontana, wydana w Polsce pierwszy raz jako jedna z ksiąg Herharza Marcina Sicmnika (1568), a w 1620) roku na nowo przetlumaczona przez lckarza. Scbastiana Śleszkowskiego (zob. przyp. 3). nic tracila popularności jeszcze w XVIII wicku. Dziclo to zostało po raz pierwszy ogloszone w Bazyleiw 1563 roku. a powstalo.jak piszc autor przedmowy do czytchnika, w wyniku wyrzutów sumicnia pośmicrci pewnego chorego, źle leczonego przez cyrulika. Ponieważ Pedemontan, jako doświadczony medyk, i jak sam o sobic mówi. posiadacz wiclu tajemnic. byl poproszony przez owego .,barwicrza” o darmową radę, nic chcial mu jej udziclić. gdyz wiedzial, że nieuczciwy cyrulik będzic kurowal chorego i weźmie za to niezaslużone pieniądze. Gdy w wyniku zlego leczenia chory na kamicń zunarl, a niedonczony lekarz rozlożyl ręce, Pedemontan zawstydzil siç swojego postçpowania i postanowil swoje „tajemmice” lekarskie udostępnić wszystkim potrzebującym. Przcdmowa ta. jak twicrdzi Zbigniew Bcla, prawdopodobnic została dodana późnicj w celach komercyjnych. by zwiększyé popyt un Tajemmice. Sam autor - Alcksy z Picmontu (ok. 1470-1550) - mial być zakomnikiem, alchemikiem i medykicm, prawdopodobnic pehniącym funkcje osobistego lekarza Joanny Aragońskiej, zwancj Szaloną. Jest równicż autorem alchemicznego traktatu o sublimacji (podaję za: Z. Bcla, Alek-

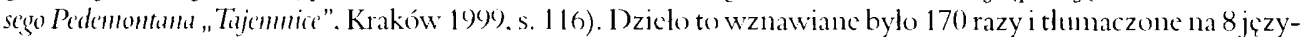
ków. W jeczyku polskim miało 8 uydań w latach: 1568, dwukrotnic 1020), 1737, 1750, 1758, 1786, 1788. Tak wielki sukces wydawniczy można thunaczyć tym. że Pedemontan tytulowal się wiclebnym, a w powszechnym monicmaniu zakonnicy micli duż doświadczenic w medycynic. stąd popularność i wysoka cena ich receptariuszy; poza tym księga ta zawicrala az trzydzicści przepisów na lckarstwa przeciw dżumic, napisana byla cleganckim stylem i nie zawierala z początku prostackich recept (za: Z. Bela, op. cit., s. 348).

${ }_{37}$ A. Pedemontan. op. cit., s. 6. 
...weźmi jaje krucze a utlucz je na miednicy mosiędzowej, a ogoliwszy miejsce, gdzie wlosy czarne mają być, tedy pomazuj, ale póki nie uschnie, póty miej oliwę w uściech: albowiem by żeby poczerniały, a czyń to w cieniu dnia trzeciego. (...) a jeśli bielić chcesz, lajna jaskólcze z wołową zólcią zetrzy a pomazuj ${ }^{3{ }^{\circ}}$.

Logika tej recepty, nawiązującej do magii sympatycznej, wydaje się prosta: aby uzyskać czarny kolor włosów, bierze się zalążek najgłçbszej czerni: krucze jajo. Podobnie należy postąpić w przypadku bielenia włosów. Większość tych przepisów, może poza nicktórymi réceptami na kremy, jest pozbawiona logiki empirycznej, więc pewnie znaczenie miala wiara w ich skuteczność, zwłaszcza że większość z nich opatrzono działającymi psychologicznie nazwami: „lekarstwo osobliwe”; „lekarstwo doświadczone; ...pewne; . . skuteczne”; ,tajemnica niepospolita”, które pozytywnie nastawiały do nich użytkownika, a wcześniej-kupującego książę.

Piersi kobiece, według ideału urody tantych czasów, mialy być niewielkie, zatem sporym zmartwieniem panien i ich matek bylo, aby powstrzymać ich wzrost. Pedemontan podaje zatem sposób, ,jako się zbytniego rośnięcia cycków bronić”:

...tłucz weszkę ziele z liściem, w occie roztwarzając, przykladajże to plastrem na cycki panieńskie, a to je powściągnie od dalekiego rościenia, tak że skromne będą, tylko że czasu potrzeby nie będzie w nich mleko" ${ }^{39}$.

Brak mleka jednakże nie był dla szlachcianek i arystokratek problemem, gdyż dzieci na ogół i tak karmione były przez manki, a matki często starały się, by mleko w ich piersiach wyschło. Wenecjanki okładały je szafranem i miodem, damy niderlandzkie - chustką moczoną w oleju rzepakowym. Obwiązywały sobie równiez pièrsi, „wypychając je ku górze, żeby nie wisialy" "11. Tutaj jednak tłumacz Pedemontana, Sebastian Śleszkowski, zaapelowal do Polek, by same karmiły swoje dzieci, zwłaszcza płci męskiej, bo

...zgoła trudno o zdrowego syna; rzadki, który by nie chorowat, jeśli nie na ciele, tedy na umyśle ${ }^{+1}$.

Komentarz ten mógłby się wydawać przesadzony, gdyby nie fakt zawicrania przez arystokratów małżeństw w tej samej rodzinie (w celu uniknięcia rozdrobnienia fortun), z których rodziły się upośledzone dzieci. W Rzeczypospolitej dotyczylo to zwlaszcza wygasających w XVII wieku rodów możnowładców, na przyklad Ostrogskich ${ }^{4 ?}$.

\footnotetext{
3* M. Siennik. Lekarstria dośmiadeane..., s. 46.

${ }^{34}$ A. Pedemontan, op. cit., s. 77.

"Ibidem, s. 83.

$"$ Loc. cit.

42 O tym wygasającym rodzic historyk Zbigniew Kuchowicz pisal. ze jego przedstawicick nosiliznamiona degeneracji: „Wiadomo. ze wyniszczyły ich przede wszystkim choroby umyslowe i rozmaite naduzycia. Konstanty Wasyl to psychopata, megaloman, cpileptyk, ulegający napadom szalu. Aleksander słynął z pyclıy, gwaltowności, dobila go trucizna wmieszana do afrodyzjaku, jego synów cechowaly zaburzenia psychicznc, zmarli
} 
Włosy, niezależnie czy to u mężczyzny, czy kobiety, miały być bujne. Eysina była nieestetyczna, zatem smarowano ją źócią wieprzową, olejkiem migdałowym, krecią krwią albo psim sadłem $^{+3}$, licząc na porost włosów. $Z$ drugiej jednak strony, czoło, zwłaszcza u kobiet, miało być bardzo wysokie, zatem polecano środek, którym smarowano skórę na czole:

...wyrwawszy włosy, namazuj czoło krwią z zielonych żabek, albo rdzą żelazną z moczem rozpuszczona albo krwią nietoperzową, a nie wyrosną więcej ${ }^{\text {th }}$.

Podobnie modne damy usuwać mialy sobie rzęsy z powiek, aby przypominały łupiny orzecha. Przepisów na środki depilujące u Pedemontana jest dziesięć, w tym jeden całkiem zbliżony do dzisiejszych plastrów z woskiem ${ }^{+5}$. Receptę na depilator znaleźć można także już w najstarszym herbarzı Falimirza, który zalecał przyrządzanie go w następujący sposób:

Weźmi wapna niegaszonego ośm uncyj, korzenia fiołkowego startego jedna uncyję, auripigmentu z apteki pól uncyjej. Ty wszystki rzeczy, starszy na proch, zmieszaj spolem, a gdyć potrzeba, weźmi część tych prochów, rozpuśćze czystą wodą, tak by bylo jako ciasto albo maść, a tego przykładaj z plastrem na miestcze, gdzie włosy są, a chcesz, żeby nie były, daj na włosach leżeć, aż uschnie, a potym wcieraj drewnianym abo czym ostrym onę maść, potym umywaj to miestce wódką różaną th.

Jeśli chodzi o oczy, prócz sposobów malowania powiek poradnik Pedemontana zawiera także przepisy przefarbowania tęczówek z zóltych na czarne:

...huszczyny zielone włoskich orzechów miałko uwierć, a jeśli trzeba, wody przylej, aby gęstym ciastem było, które na placki rozgniotszy, na oczy przykladaj, a sczernieją od tego wnet ${ }^{+7}$.

Jak wyglądaly powieki modnej damy po takim zabiegu, można sobie wyobrazić, biorąc pod uwagę barwiące whaściwości zielonych hupin orzecha.

w wicku 20-21 lat”, natomiast córka Anna Alojza z Ostrogskich Chodkiewiczowa „przeciwnic do swych męskich przodków, którycl cechowala crotomania. czula odrazę do życia scksualnego, ulegala halucynacjom", byla fanatyczką religijną. posuwala się do gwaltów i tumultów rcligijnych. a jako gorliwa katoliczka odbicrala prawosławnym to. co zapisał im jej dziad Konstanty Wasyl. Odważyla siç nawet. pod wplywem jezuitów, przenieść cialo zmarlego trzydzicści lat wcześniej Alcksandra z ccrkwi prawoslawnej do unickiej. thumacząc. że ojcicc nawrócil się na katolicyzm przed śmicrcią. Spowodowato to rozruchy na tle religijnym i w rezultacie przymusową unię wyznawców prawoslawia z katolikani. „Przestępcy” micli do wyboru: przyjęcié unii lub śmierć kwalifikowaną (Z. Kuchowicz. ITizermuki miepospolitych nieu'ust staropolskich XI T-XI II wieku, Łódź 1974, s. 185$)$.

t3 Zob. A. Pedemontan, op. cit.. s. 11.

$"$ Ibidem. s. 15.

t5 Zob. ibidem, s. 14.

th S. Falimirz, op. cit., k. 21.

${ }^{47}$ A. Pedemontan, op. cit., s. 25. 
Ciało, gładkie, białe i bez piegów, miało wydawać z siebie subtelny zapach. Recepty na perfumy i wody toale towe znane są od setek lat. Nasze poradniki również je zawierają. I tak, herbarz Falinirza przytacza przepis na perfunny z wơdki różanej i piżma oraz na wodę po goleniu. Aleksy Pedemontan podaje wiele recept na wódki, gałki zapachowe do noszenia przy sobie, pachnący tój do smarowania rękawic, perfumy do ubrań, proszki do perfumowania szat, olejki zapachowe do ciala. Myliłby się jednak ten, kto, biorąc pod uwagę obniżenie częstotliwości mycia w XVII wieku, wziątby owe substancje zapachowe jedynie za środek pozbycia się niezbyt przyjenmych zapachów ciała. Perfumy służyly przede wszystkim do odganiania dżumy, gdyż wierzono, iż można uniknąć choroby przez noszenie przedmiotów zapachowych i wdychanie dobrego - wonnego - powietrza, niezepsutego chorobą i fetorem zgnilizny. Nie zmienia to jednakże faktu, że perfumowano się obficie, również w czasach wolnych od chorób zakaźnych, licząc na powodzenie u płci przeciwnej.

Twarz kobieca miała być delikatna, bez skazy, stąd „ Pedemontana recepty na bielenie lica (6 przepisów), spędzenie piegów, pryszczy (9), zmarszczek (15), rumienienie policzków (11). Dość często powtarza się w tych przepisach wódka palona z młodych gołębi lub kurcząt, karmionych jajkami na twardo, z dodatkiem olejków kwiatowych. Żartem wydaje się „wódka na odmłodzenie lica baby starej, aby się zdała we dwudziestu albo dwudziestu pięciu leciech":

...weźmi 2 nogi cielęce a warz je w 18 funtów wody rzecznej, aż 9 funtów wywrze, włóż w onę juclę̣ ryżu funt jeden, ośrzodki chlebowej w mleku moczonej od jednego chleba, masła świeżego niesolonego dwa funty, białków z skorupkami od 10 jaj świeżych. To wszystko, zmieszawszy, warz, potym wypal, aby wszystka wódka wyszła, w tę wódkę potym włóż po trosze kamfory, hałumu cukrowatego, a będzie na to wyborna ${ }^{+\$}$.

Już sama forma podania tytułu recepty stawia jej skuteczność pod znakiem zapytania, 11awet dla użytkownika sprzed kilku wieków, ale najwidoczniej nazwa obliczona byla na skutek psychologiczny. Poza tym w Tajemnicach Pedemontana uderza częsty brak precyzji w odmierzaniu składników. Wyżej przytoczony przepis jest jednym z nielicznych, gdzie miara każdego elementu została podana. Częściej pojawiają się recepty takie jak „barwiczka niepospolita”:

Weźmi prochu czerwonego zandału, octu mocnego dwakroć palonego, każdego z tych, co chcesz, zmieszawszy, warz w ogniu, lekkiego przylożywszy trochę hatunu ${ }^{+\prime}$.

Stąd wiadomo, że nie jest to ksiązka dla aptekarzy, i że, jak zapewne wierzono, owe „sekrety" nikomu raczej nie powinny zaszkodzić.

\footnotetext{
${ }^{4}$ Ibidem, s. 50. Nawiasem mówiąc. krem ten zawicra kolagen, skladnik nowoczesnych kremów przeciwzmarszczkowych.

14. Ibidem, s. +7.
} 
Z kobiecością niewątpliwie związany jest erotyzm i macierzyństwo. Wydawałoby się, że obie te sfery będą tożsame, jednak w poradnikach są omówione na osobnych miejscach, poza tym same kobiety, o czym wieny z immych źródeł, próbowały rozdzielić seks od prokreacji ${ }^{50}$. W poradnikach również można znaleźć informacje na temat środków antykoncepcyjnych i poronnych, ale niezebranych w jednym miejscu. Syreniusz i Marcin z Urzędowa, podając działanie ziól, informują również o tym sposobie jego użycia, nie komentując tego jednocześnie. Brak komentarzy natury moralnej jest w ogóle charakterystyczny dla renesansowych herbarzy. Wielokrotnie podawane są na przykład ziołowe środki i sposoby na spędzenie płodu, bez troski autorów o skutki tego czynu. Sądzę, że wynika to być może z fáktu, iż w dawnej Polsce, chociaż prawo surowo karało śmiercią matki wywolujące poronienia, w sferze obyczajowej nie uznawano tego za zbrodnię, byle rzecz przeprowadzona była dyskretnie. Poza tym autorzy liczyli najwyraźniej na inteligencję odbiorców, którzy, widząc takie działanie zioła, będą unikać zagrożenia. Jedno z nielicznych ostrzeżeń pojawia się przy paproci, która

...nie ma być dawana paniam, bo brzemiennej kazi płód w żywocie, a insze czyni niepłodne wiecznie ${ }^{51}$.

W przeciwieństwie do renesansowych, barokowe poradniki kładą nacisk na zdrowe potomstwo. Ich autorzy całe akapity poświęcają niemoralıości kobiet stosujących środki wywołują̧e poronienie, a także tych, które, ze względu na lęk przed deformacją ciała, nie chcą mieć dzieci.

Szukano także sposobów na zwiększenie aktywności seksualnej mężczyzn, podając im szałwię zmieszaną z winem ${ }^{52}$, lubczyk czy też napój z mieczyka ${ }^{53}$. Trzeba było jednak wiedzieć, który podać, gdyż można było mimowolnie sprawić skutek wprost przeciwny do zamierzonego: afrodyzjakiem i środkiem pobudzającym męskie nasienie miał być mieczyk

"Najciekawszym i jednocześnic najstarszym przykładem formul magicznych jest, pochodzący z klasztoru cystersów w Rudach Raciborskich. Katalog maguii Rulolfa z XIII wicku, w którym skrupulatny muich, chcąc przestrzec wspótbraci spowiedników przed dzialanicm diabelskim. stworzyl dzieło jedyne w swoim rodzaju na ziemiach polskich z tego okresul spisal zaklęcia i zabiegi magicznc, które czynily kobiety, aby zapewnić sobic i swoim dzicciom powodzenie. zdrowic i miłość. Jest to przyklad tak zwancj biakcj magii, czyli czarów do-

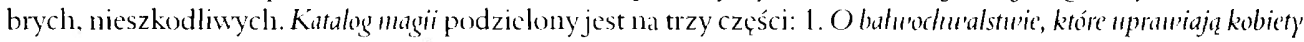

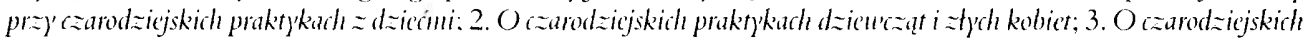

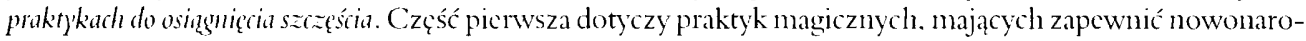
dzonym dzieciom zdrowie, powodzenie i milość ojcowską: „Dziccijeszcze bardzo delikatne wsadzają do worka. aby spały. (...) Uszy zajęcy nóźki kretów i wiele imuych rzeczy kladą do kolyski, a czynią to, aby dzieci nic płakaly. (...) Układają kupki mąki i soli, które liżą, aby mialy obficie mlcka. Ojcu pokazują najpicrw wiclki palec nóżki dziccka, a nie twarz. Z blony porodowej dziecka odgryzają trzy kawalki, które zanieniwszy w proch, dają ojcu do pożywicnia. aby kochal dziccko. I jeszcze inne odrażające praktyki wykonują z tą bloną porodową. (...) Podubnic po chrzcic dziecka nóżkami jego dotykaja gołego oltarza, sznur dzwonu kładą mu na usta, rączkç kladą na księgę̧. aby siç dobrze uczyło. a prześcieradlem z oltarza glaszczą jego twarz, aby bylo piękne. (...) Z koszullką dziecka robią czary. aby wszystko, co zgubi, znalazto" (E. Karwot, op. cit., s. 285-290).

${ }^{51}$ Marcin z Urzçdowa, Herburz polski. s. 140.

52 Zob. ibidem. s. 153.

5 Zub. ibidem, s. 159 . 
wyższy, z kolei o niższym twierdzono, że powoduje obniżenie pożądania i sprowadza nieplodność. Działanie antykoncepcyjne miało mieć również noszenie przy sobie ziela heliotro$\mathrm{pu}^{5+}$. Oczywiście istniały również formuly magiczne, mające zapewnić brak potomstwa, ale o tym poradniki milczą.

Interesująca wydaje się receptura ua lek dla mężczyzn „na słabość sil z zbytniego złączenia" $\overline{5}$, którego kubeczek „chory” ma pić codziennic rano, w którego skład oprócz bukwicy wchodzi mleko kobiece, sadło kapłonie, orzechy limbowe, słodkie migdały i miód ${ }^{50}$. Zastanawiająca jest ta recepta, ale jeśli weźmie się pod uwagę dużą nieraz różnicę wieku pomiędzy małżonkami, wówczas staje się ona oczywista w receptularzu przeznaczonym dla kobiet.

Dość ciekawe i znane do dziś wierzenia na temat ciąży, matki i dziecka znajdują się w traktatach polożniczych. Szczególne miejsce w tych dziełach zajmuje kwestia rozpoznania i urodzenia martwego płodu oraz gorączka poporodowa, które musialy przydarzać się w wielu wypadkach, o czym świadczy mnogość porad na ten temat. Wreszcie w niektórych traktatach zawarte są informacje na temat pielęgnacji niemowląt i ich chorób. Pod tym względem najciekawsza i najobszerniejsza jest księga o położnictwie, umieszczona w ziclnikach Falimirza, Spiczyńskiego i Siennika.

Magia i wierzenia dotyczące ciąży i porodu przetrwały bardzo dhugo w kulturze curopejskiej. Ewoluowaly one z czasem i były zależne od micjsca i kultury regionalnej, ale fakt, że wiele elementów magicznych, spisanych w poradnikach medycznych, będących często thumaczeniem dzieł zagranicznych, zakorzeniło się w naszej kulturze, świadczy o przyjaznym gruncie, jak i o uniwersalizmic tych wierzeni w społecznościach kobiecych, bo tak można chyba nazwać świat, związany z wydawaniem na świat potomstwa. Był on raczej zamknięty dla mężczyzn, którzy rzadko pomagali w porodach, czasem tylko wspierali kobiety, gdy proces się komplikował i przeciągal ${ }^{57}$. Ciążę i poród otaczal szereg wierzeń i praktyk, których efekt nieświadomy mężczyzna mógł tylko popsuć.

Wierzenia te są do dziś obecne w naszej kulturze. W pierwszych trzech polskich zielnikach, w których umieszczony jest traktat o położnictwie, thumaczenia Andrzeja Glabera, pojawiają się liczne informacje, wartościujące narodziny dziecka plci męskiej. Między innymi przekazuje on do dziś znany przesąd, że córka odbiera matce urodę, a syn dodaje:

A przed to jest pierwsza nauka: jestze ona niewiasta przed poczęciem była blada, a po poczęciu rumiana na licu, znak jest, że z synem chodzi. Drugi znak: jeśliże niewiasta, zastąpiwszy, nie ma wielkiego obciążenia w sobie we wszystkich

\footnotetext{
Zob, ibidem, s. 163.

55 A. Pedemontan. op. cit., s. 196.

56 Można zaryzykować pytanic, jak bardzo cksploatować musial się mężczyzna w ciagu jedncj nocy, skoro co rano zalecano mu środek wzmacniający a także, kto mu go przyrządzal? Zapewne kochająca żona, zwhaszcza w sytuacji malżcństwa niedobranego pod wzglçdem wicku...

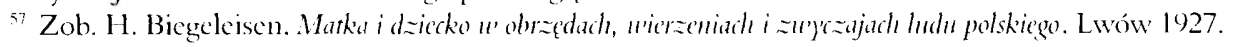


czlonkoch, znak jest, że syna w żywocie nosi, a jeśli zasię bardzo mdła, leniwa, obciążała, znamię, iż dziewka będzie ${ }^{58}$.

Innym wierzeniem, pozostalym do dziś, jest sprawa strony brzucha, na której umiejscowiony jest plód. Jeśli po prawej — oznacza syna, jeśli po lewej — córkę ${ }^{51)}$. Pogląd ten wywodzi się, jak sądzę, jeszcze z nauk Arystotelesa o dwurożnej budowie macicy. Strona prawa, dająca lepsze warunki, cieplejsza i suchsza, jest miejscem, w którym rozwija się wartościowszy płód męski; natomiast w lewej - wilgotnej i chłodniejszej, a przez to pośledniejszej natury, rozwija się dziewczynka.

Poza symptomami płci mającego się urodzić dziecka, które są dość znaczące, skoro zachowaly się w kulturze tak dlugo, charakterystyczne dla tego traktatu są rady dla położnej, która ma być rozsądna i w razie przeciągającego się i bolesnego porodu ma pocieszać położnicę, mówiąc, że na pewno urodzi syna, albowiem bardzo chętnie o tym słyszą brzemienne panie ${ }^{(1)}$. O sprau'ach brzemiennych Glabera zawiera też kilka wierzeń i wróżb na temat przyszłych ciąż kobiety rodzącej. Należało przyjrzeć się pępkowi pierworodnego, zaraz po narodzeniu, zawiązanego na trzy palce od brzucha. Jeśli na tym kawałku pępowiny były guzy, od ich ilości miała zależeć liczba następnnego potomstwa. Gladka pępowina zwiastowala ostatnią ciążę. Zólte guzy wieszczyły synów, białe — córki ${ }^{i, 1}$. W poradniku brak natomiast informacji na temat sposobu pozbycia się łożyska, a także postępowania z odpadniętym pępkiem ${ }^{02}$, istotnego w medycynie ludowej, gdyż wydzieliny ciała mialy znaczenie magiczne: niechronione, mogły poprzez rzucony urok działać na szkodę matki dziecka. Glaber jednakże zwrócił uwagę na wybór mamki, gdyż, jak wierzono, dziecko przejmuje z mlekiem jej charakter. Stanowczo odradzal szwaczki i hafciarki, ze względu na ich swobodne obyczaje ${ }^{63}$.

Wiele elementów myślenia magicznego, empirycznego oraz wiedzy naukowej tamtej epoki przetrwalo w postaci recept na dolegliwości w czasie ciąży, trudnego porodu i pielęgnacji niemowlęcia. Należy tutaj zwrócić uwagę, iż dużym problemem byla niepłodność, poronienia, obunarcie płodu w macicy, ciężki poród z komplikacjami w ułożeniu plodu, a także urodzenie lożyska, które często kończyło się gorączką poporodową i śmiercią matki. Ze względu na obszerność materiału należy mu się jednakże osobny artykuł.

Poradniki ukazują zatem obraz kobiety, która dba o swoje ciało, starając się nadążyć za ideałemn piękna niewiéściego tamtych czasów. Uwidocznione zostały jej lęki przed starością i oszpeceniem ciążami, które objawiają się w liczbie recept na kremy, „wódki” (wodne leki roślimne), a także sposoby na przeciwdziałanie deformacji piersi. Okazuje się przy tym, że kobie-

\footnotetext{
${ }^{5 k}$ M. Siennik. Herbarz.... k. +41 .

${ }^{54}$ Zob. ibidem, k. H+2.

(1) Zob. ibidem, k. $4+7$.

6) Zob. ibidem. k. 403 .

62. Jeszcze kilkadziesiąt lat temu żywy byl zwyczaj, by zachować pępek dziecka aż do rozpoczęcia przez niego nauki w szkole. Ponyślnc rozwiązanic przez nicgo węzzla mialo gwarantować dobrą pamiçć i latwość przyswajania wiedzy.

${ }_{6.3}$ M. Siennik. Herbarz.... op. cit.. k. +65.
} 
ty nie realizują wcale chętnie idealu matki, która bezgranicznie poświęca się własnym dzieciom: szlachcianka pozostawia wykarmienie niemowlęcia mamce, sama starając siç pozostać piękna jak najdłużej. To pragnienie wykorzystują nieraz autorzy poradników, którzy (podobnie jak dzisiaj) oferują in cudowne środki, mające moc poprawienia natury i zniwelowania zniszczeń wywolanych działaniem czasu. Obraz damy tantych czasów, która sprawia przyjemność własnemu ciału, nie słuchając nawoływań do umartwiania się, staje się przez to bliski wspólczesnej kobiecie.

\section{Dom}

Poradniki już na początku ukazują szeroki zakres tematów, w jakich będą się poruszać. W księdze o chorobach glowy obok sicbie stoją recepty na autentyczne schorzenia, takic jak ból głowy, parchy, wszy, strupy, padaczkę, głuchotę, a także porady, co zrobić, ,gdy co do ucha wlezie”, gdy do oka wpadnie, jak leczyć podbite oko, ,na śmierdzenie z nosa i ust”, na pryszcze, na zmarszczki, piegi, zbytni rumieniec; bielenie, czennicnie, kędzierzawienie, żólcenie i czerwienienie włosów, na łysinę, porost włosów ${ }^{\text {(t) }} \mathrm{i}$ wiele innych. Charakterystyczne dla poradników medycznych w ogóle jest umieszczanic w nich porad dość luźno związanych ze zdrowiem. Obok przepisów na wódki ziołowe, nalewki, maści i plastry pojawiają się sposoby przyrządzania pierników, konfektów, owoców kandyzowanych, atramentu, odplamiaczy, farb, złocení, środków owadobójczych, a wreszcie alkoholı - głównie wina i piwa.

Z alkoholem związanych jest jeszcze kilka cickawych recept, które ukazują niezmienność ludzkiej natury pod względem jego używania i... nadıżywania.

Jeśli ktoś chcial mieć tak zwaną ,mocną głowę",

...przed piciem ze ćwierć godziny trzeba, by zjadl trzy abo cztery jądra brzoskwiniowe albo tyle jąder gorzkich migdałów, a na to wypił oliwy, albo z migdałów słodkich łyżkę. To nczyniwszy, może pić co chee ${ }^{6 \bar{s}}$.

Jest również sposób, by się upić bez szkody, a także ,jako pijanego otrzeźwić” — trzeba napoić go dużą ilością octu ${ }^{\text {r.t. }}$ Jeśli ktoś przesad ził z alkoholem, mógł sobie pomóc następująco:

Jeśliś sobie pozwolit i pil co wieczór sila,

Zażyj sierści bestyi, co cię ukąsiła,

To jest popraw nazajutrz, uczujesz ulzenie,

Byle tylko recepta nie szla w zwyczajenie ${ }^{67}$.

at Zob. A. Pedemontan, op. cit., s. 6-50); M. Sicnnik, Lekarsu'd dośniadezone.... s. 47-60): Compendium medi(um)..., s. 37-51.

4.5 A. Pedemontan, op. cit., s. 21.

th Zob. ibident, s. 22.

47. Aptcka..., s. 20 . 
Benedykt Chmielowski w Nou'ych Atenach napisze:

Kto się upije winem, niech klin wybije klinem ${ }^{6.8}$.

Jeśli jednakże ktoś ma już dosyć pijaka w domu, może spróbować wyleczyć go z tego zgubnego nawyku:

Jeśli clıcesz komı wino obrzydzić, aby go nigdy nie pijał, włóż w nie trzy abo cztery węgorzów, a gdy pozdychają, wyjmij je, a wino przecedź, dajże je pić pijanicy opiłemu, od tego czasu mu obmierznie"

Żywotność tej metody najwidoczniej byla duża, jej echa przetrwaly do dnia dzisiejszego, skoro na temat takiego kurowania pijaków, w nieco zmienionej wersji, krążą jeszcze aneğ $\operatorname{doty}^{70}$.

W popularnych książkach medycznych zawarte są więc porady dotyczące chorób, zdrowia, kosmetyki, kuchni, cukiernictwa, różnych rzemiosł, a nawet sztuczek magicznych. W naszych poradnikach, w rozdziałach poświęconych cukiernictwu, przeważają przepisy zwlaszcza na te słodycze, które można bylo kupić w aptece: likwory, konfitury, octy, makowce, pierniki, orzechy w cukrze, owoce kandyzowane, figurki z cukrowego ciasta i konfekty z rózą pod różnymi postaciami, jako posilające serce. Pierniki były popularne w kuchni staropolskiej, a zwłaszcza modne wówczas pierniki toruńskie. Najwięcej sposobów ich przyrządzania podaje Compendium medicum. Oto przykład:

Pierniki osobliwe

Weź maki pszennej lotów 3, cukru utłuczonego i przesianego funtów 2, migdałów na masę utłuczonych funt, cynamonu łotów 4, imbieru 1 i pół łota, gałek muszkatowych 3, zółtków jajowych 10, wina ile potrzeba, zagnieć ciasto, formuj pierniki, pozynguj lukrem i piecz ${ }^{71}$.

Na przykładzie przepisów na potrawy mięsne możemy odtworzyć obraz czysto użytkowego podchodzenia przez ludzi tantych czasów do zwierząt i nieliczenia się z ich cierpieniem. Przytoczony nizej przykład podawania gęsi być może istotnie, jak sądzi Zbigniew Bela, autor monografii o Pedemontanie, został dolożony później, gdyż zaskakuje czytelnika okrucieństwem, a z drugiej strony chęcią zadziwienia, zaskoczenia i olśnienia biesiadników.

${ }^{6 x}$ B. Chmiclowski. Noure Ateny'... opr. J. i J. J. Lipscy, Kraków 1966, s. 530.

${ }^{6 y}$ A. Pedemontan. op. cit.. s. 22.

7) Oto przyklad: „Żona pijaka skarży siç sąsiadce. że nie może już z tim wytrzymać. Na to ta podaje jej sprawdzony sposób na obrzydzenic mçżowi wódki: "Nalej do wanny wódki i whóz do nicj zdechlego kota. Gdy twój mąz to zobaczy. nic wypije już ani kicliszkan. Żona tak zrobila. a gdy mąz zamkną̧ siç w lazicnce i dlugo nic wychodzil. zerknçla przez dziurkę od klucza i zobaczyła pustą wannç oraz męża, który mówil, wykręcając kota: "Koteczki1. jeszcze kropelkę!”” (Zasłyszane).

${ }^{71}$ Compendium medicum, s. 630 . 
Aby upiec gęś żywcem, należy ją oskubana przypiekać na wolnym ogniu, ale tak, żeby nie zdechła, chłodzić jej głowę wodą, karmić jabłkami i często polewać tłuszczem. Woda ma chłodzić wnętrzności, jabłka spowodują opróżnienie jelit, a mięso się upiecze:

Wyjmuj ją z ognia i nieśże przed goście. Za każdym razem, gdy jej kto sztukę ukroi, będzie wrzeszczała, gęgala, tak że ją niemal pierwej zjedzą, niźli żywą przestanie byćc ${ }^{72}$.

Gospodarz zaskoczyć może gości nie tylko efektownie przyrządzonym jadlem. Również jego dom, dzięki sztuczkom, zawartym w poradnikach, może nabrać nowego wyglądu i mamić oglądających go złudzeniami bogactwa i mirażami. Pedemontan podaje sposoby, jak sprawić, by dom wydawał się złoty, jak farbować bądź złocić kwiaty na grządkach, co zrobić, by zdmuchiwane świece nie gasły, a ogień palił się pod wodą ${ }^{73}$. Goście nie powinni się nudzić, zatem można ich zabawiać sztuczkami, przyrodzonymi dziwami (autor odżegnuje siç od magii), jak bezpiecznie brać roztopiony ołów golą ręki, , ,jako jaje uczynić większym niż człowiecza głowa”, co zrobić, ,aby jaje na powietrzu latało"7t . W tym ostatnim wypadku tłumacz pozwolił sobie na sceptycyzm i dopisek:

Zostawmy ten sekret tamtym krajom, w którym go doświadczono: bo un nas, kędy nie tak bardzo słońce grzeje, żadne jaje ku górze nie poleci, chociażby mu skrzydla przyprawit ${ }^{75}$.

Poradniki stanowią więc kompendia wiedzy nie tylko medycznej, ale również pomocnej w gospodarstwie domowym. Nasuwa się więc wreszcie pytanie o czytelnika przewidywanego przez autora. Zalożyliśmy na początku, że drukarze przeznaczyli te książki dla bogatego mieszczaństwa, duchowieństwa i szlachty, gdyż tych stać było na kupno kosztownych dzieł. Wiemy, dla kogo przeznaczyli je autorzy, gdyz zaznaczyli to w dedykacjach. Przyjrzyjmy się dokladniej, kto był lub mógł być realnym ich odbiorcą.

Z pewnością potencjalny czytelnik nie musial znać łaciny, gdyż książki te wydano w języku polskim. Trzeba było, by mial niejaką wiedzę i umiejętności z zakresı przyrządzania potraw, ponad to techniki robienia nalewek, wódek ${ }^{76}$, olejków; by znal się choć trochę na astrologii, ale podstawy tejze nauki wyłożone byly w pierwszych ziclnikach, pisanych przez ludzi bez wyższego wyksztalcenia, a więc przeznaczonych dla czytelników podobnego statusu. Zielnik

72 A. Pedemontan, op. cit., s. 340 .

72 Zob. ibidem, s. 34 .

${ }^{74}$ Powtórzony późnicj w Non'yeh Atenad Chmiclowskiego.

${ }^{75}$ A. Pedemontan, op. cit. s. 339. Takicgo komentarza brakuje w opisic chorób. mimo ze Sleszkowski byl lekarzom.

7h "Aczkolwickem nadmicnil o sprawowanitu wódek, o palenius. a wszakze nieraz dostatecznic nic potrzeba, a to zwlaszcza nie wypisalem, jako alcmbik przyprawować i wszystko naczynic ku paleniu, albowicm by bylo przedlużenic i próżne pisanic, ale gdy kto będzie cheial wódki palić, musi siç oczywiście nauczyć od tych. którzy picrwej unicją. albowiem jedni palą w alembikach. a drudzy po prostu. Juz tedy będę pisal o mocy wódek i ziól rozmaitych" (S. Falimirz, op. cit., k. 3). 
Syreniusza jest zatem najbardziej ambitnym przedsięwzięciem, które pod względem wiedzy stawia czytelnikowi największe wymagania. Syreniusz wymaga znajomości astrologii, nieco alchemii, uniejętności przyrządzania olejków, wódek, maści, plastrów, również znajomości anatomii, gdyż nie robi na ten temat wykładu w swym dziele, mimo że podaje recepty na "lekarstwa doświadczone".

Z kolei Marcin z Urzędowa, który za cel wziąl sobie poprawienie blędów Falimirza, swoje dzieło kieruje do prostego czlowieka. Do czytelnika przemawia jak lekarz do pacjenta, stosując formę drugiej osoby liczby pojedynczej, co ma spowodować, że ten nabierze do niego zaufania. Chcąc przekazać wiedzę, Marcin z Urzędowa dostosowuje się do poziomu umyslowego zakładanego przez siebie odbiorcy, co widać wyraźnie, gdy przy okazji omawiania jednego z ziół robi wykład o jelitach ${ }^{77}$. Ten sam autor walczy z przesądami i wierzeniami dotyczącymi chorób, mówiąc do „prostego człowieka”:

...bo częstokroć zwracają mlodzieńcy abo dziewki takowe robaki, i powiedaja niewiasty, że to z zadanego jadu, z którego się zamnożyly jaszczurki; i mówią, że gniazda jaszczurek wyrzucił wracając ${ }^{78}$.

Jest to zatem czytelnik bez większej wiedzy medycznej, ale za to posiadający zdrowy rozsądek i... dostęp do kuchni. Z poradników przecież równiezż można się dowiedzié, jak szybko upiec stare mię̧so, naprawić skwaśniate wino, zjełczały olej, zrobić pierniki i konfitury, ocet, perfuny, kremy i środki depilujące. Mało prawdopodobne, by zajmowali się tym mężczyźni. Do przyrządzania leków trzeba mieć laboratorium, a w domach wystarczala kuchnia, więc robieniem lekarstw i innych środków potrzebnych w gospodarstwie domowym zajmowały się kobiety.

W poradnikach pojawiaja się uwagi na temat leczenia chorych przez niewiasty. Na przyklad u Marcina z Urzędowa znajdujemy zapis, że panie krakowskie kupują zioła od bab i w domach przyrządzają leki. Autor przestrzega je zatem, aby kupowaly od doświadczonych, bo mogą się otruck ${ }^{77}$. Takich uwag ze strony krakowskiego medyka jest więcej.

Również jeśli drzeworyty zdobiące polskie zielniki przedstawiają ludzi, w większości ukazują kobiety przyrządzające preparaty ziołowe, zbierające zioła, handlujące nimi, wyrabiające olejki, wódki, pielęgnujące chorych — jak w herbarzach Falimirza i Siennika. Jeden z ciekawszych drzeworytów przedstawia dwóch lekarzy z aureolami wokół głowy i kobietę, sięgającą do chusty z zebranymi roślinami. Ponieważ ryciny nie są opisane, można jedynie wnio-

\footnotetext{
77 ..Przy tym masz wiedzicé prostakı, że (...) w czlowiecze sześcionaki jest jelito, miejscem i sposobem naznaczono, aczkolwick nierozdzichnic. Picrwszc. które od żołądka idzic na dwanaście palców, zową drodemum: po nicj drugie dwie cienkic. jedno zową ieinnum. jakoby rzckł: „zawżdy próżne”: drugie illeos zową, po polsku kiclbaśnice oboje. a w tych bywa boleść, którą zową illinca: bywa to ciężkie gryzienic kolo pẹpka. Czwarte jelito jest colon. które zową jątrznica i w którym bywa kolika. Piąte (...) kątnica, szóste rétum. to jest proste, które idzic aż do samcj dziury w stolcu" (Marcin z Urzçdowa, op. cit., s. 30).

${ }^{7 *}$ Marcin z Urzędowa, op. cit., s. 5.

${ }^{74}$ Zob. ibidem, s. 86.
} 
skować, kogo przedstawiają. Skoro dwaj lekarze zostali przedstawieni z nimbami, są nimi zapewne święci Kosma i Damian, patroni medycyny. Schylona niewiasta zaś jest zielarką, niosącą swój zbiór, być może sprzedająca zioła lekarzowi po prawej. Drzeworyt ten stawialby zatem obok patronów medycyny kobietę jako tę, która pomaga inn w leczeniu.

U Spiczyńskiego i Marcina z Urzędowa (gdyż część rycin z zielnika Spiczyńskiego znalazla się w jego Herbarzu polskim) kobiety, stare i młode, występują obok ziól, czasem są ich wielkości, ale brakuje takich drzeworytów, na których pokazany zostałby mężczyzna w wyżej wymienionych sytuacjach. Mężczyźni na ogól pojawiają się w roli medyków, cyrulików, chirurgów, astronomów i aptekarzy, do których zwracano się po pomoc, gdy nie można było poradzić sobie z chorobą domowymi sposobami. Chociaż autorzy poradników medycznych dedykowali je osobom różnych stanów i płci, uważam więc, że to kobiety były głównie czytelnikami tych książek. Był to w końcu jedyny sposób zdobycia przez nie potrzebnego in wykształcenia. Tylko niektóre książki przeznaczone były wyłącznie dla kobiet; prawdopodobnie było tak w przypadku wloskich Sekretón Aleksego z Piemontu, jak sugeruje Zbigniew Bela ${ }^{8 \prime}$.

A jak było w Polsce? Syreniusz dedykuje swoje dzieło

...lekarzom, aptekarzom, cyrulikom, barbirzom, roztrucharzom, końskim lekarzom, mastalerzom, ogrodnikom, kuchmistrzom, kucharzom, synkarzom, gospodarzom, mamkom, paniom, pannom i tym wszystkim, którzy siç kochają i obzierają w lekarstwach.

Kobiety, jak widać, wymienione zostały na końcu długiego szeregu odbiorców. Wiadomo jednak, że w ciągu wieków w polskich domach i dworach tradycyjnie od kobiet wymagano wiedzy medycznej i wpajano ją w rodzinie:

Matka uczyła córki, uczono się z książek, od sąsiadek, już umiejąca szła dopiero za mąż, przyzywała wreszcie zdolną osobç, ceniąc ją i nagradzając ${ }^{81}$.

Tak więc, nawet jeśli autorzy nie kierowali swych poradników wyłącznie do kobiet, one jednak najprawdopodobniej byly głównymi ich odbiorcani. W księgach tych znajdujeny przecież opis tego, czym kobiety zajmowały się na co dzień: zarządzania kuchnią i gospodarstwa domowego.

U Pedemontana zauważalne są nieprecyzyjne miary, sensacyjne nazwy i tajemnicze przepisy, działające psychologicznie na czytelnika jako forma chwytu reklamowego, takze sposoby na kosmetyki, potrawy i... leczenic pijaków.

\footnotetext{
* "Damy z wyżsych sfer mialy zwykle w tych czasach receptariusze analogiczne do Sekretón Alcksego z Picmontu, ponicważ przy ich pomocy zajmowaly siç, czy moze raczej zarządzaly robicnicm keków do domowej apteki, kosmetyków, kontcktów itp. - które to unicjętności byly zresztą jednym z clementów ówczesnego wychowania panicn z tzw. dobrych domów" (Z. Bcha, op. cit., s. 109).

${ }^{\text {xl }}$ Ł. Golę̧
} 
W dziele tym autor, podając przepisy, bierze także, co znamienne, pod uwagę zasoby finansowe potencjalnego pacjenta. Tajemnice zawierają recepty dla bogatych i ubogich, co bywa odnotowane w nazwie przepisu:

Wódka wypalona z dębowego liścia, bardzo wielką moc ma przeciw biegunce, dla ubogich ${ }^{\text {X2 }}$.

Na przyklad omawiając kilę, Pedemontan zapisuje bogatym receptę po lacinie do zrealizowania w aptece ${ }^{\gamma 3}$, a uboższym podaje kilka przepisów na leczenie domowymi sposobami ${ }^{84}$. Podobnie jest w wypadku innych cliorób.

Zatem kobiety, które od wieków zạjmowały się leczeniem przypadłości domowników, dopiero gdy nie mogły sobie same poradzić, wzywaly uczeńszych od siebie.

Posylano na ogól shugę do lekarza, jeśli nie chciano wydawać zbyt wiele pieniędzy na sprowadzenie medyka do tóżka chorego. W Gadkach Glaber nawet wyjaśnia, dlaczego lekarze wnioskują o stanic chorego na podstawie jego moczu ${ }^{\text {ș }}$, bez oględzin pacjenta. Otóż mocz,

....gdy jest wilgotny, z pokarmu, idąc ku dołu, począwszy od ust, wiele członków przemija, od których bierze färbę taką i owaką, jako od krwie czyrwoność, od flegmy bialość etc. A zwlaszcza więcej bierze od tej wilgoty, która w czlowiecze najwięcej panuje. Takież męcherz, gdyż jest rzecz ciężka a subtylna, tatwiej się wpuszcza i przyjnuje farbę wilgoty w ciele panującejo

Thumacząc w ten sposób, tatwiej jest dotrzeć do czytelniczki, która pewnie ma zadecydować, czy w czasie choroby posłać po medyka, czy tylko wysłać mu mocz pacjenta, bez obaw o skuteczność kuracji.

Z niemożności porozumienia się uczonego z prostym człowiekiem wywiązywały się nieraz sytuacje komiczne, o czym świadczy rubaszny wierszyk w zielniku Falimirza:

Przyszedl prostak do doktora,

Przyniósł mu w garnku znamiona ${ }^{87}$ :

„Oglądaj, panie mily doktorze,

Boć mój pan schorzal jako gorze".

Potym onego doktor zapytal,

Jestli pan stolce albo wiatry miewal.

Rzekł chlop, iż wiatru dosyć będzie,

Bo drzwi, okna otworzą wszędzie.

„Bździ, sra, pierdzi?” - doktor rzecze k niemu,

$x=$ A. Pedemontan. op. cit.. s. 176.

${ }^{3}$ Zob. ibidem. s. 116.

${ }^{x+}$ Zob. ibidem, s. 117-120.

x.s Poradniki zawicrają równicż rozdziały bądź osobne traktaty poświccone takiemu badaniu, które można było przeprowadzić samodzichnic, bez pomocy lekarza.

${ }^{x}$ A. Glaber. op. (it.. s. 6).

${ }^{\star 7}$ Mocz chorcgo. 
Dopiero chlopek wyrozumial onemu.

Ta cię z tego wystrzec może figura,

Ze cię nie będą mieć za prostego gbura ${ }^{\text {ndx }}$.

Wynikały one także z blędnej diagnozy, postawionej samemu sobie przez pacjenta:

W jelicie colon bywa kolika, ciężka niemoc, którą tak zową od jelita colon, nie jako mówią prości, iz gdy czują na którymkolwiek miejscu przypierającą niemoc albo ból, tedy wnet zowia koliką, więc poszlą słıgę do doktora, prosząc porady na kolikę, ano będzie pleura abo boleść w nerkach, abo co inszego: doktor mniema według powieści być kolikę, daje lekarstwa gorące, ano więcej zepsuje; potym winują doktora, ano każdy ma winować swe głupstwo i swą skąpośc $\hat{c}^{\mathrm{R}^{*}}$.

Zatem i tutaj widać zależność ciężaru sakiewki od postępów w leczeniu. Skrupulatne gospodynie zapewne żałowaly pieniędzy na sprowadzenie doktora, kiedy diagnozę mogły otrzymać po oględzinach moczu przez lekarza, a z terapią, przy pomocy poradników, radzily sobie same. W większości jednak wypadków, jak piszą autorzy ziclników, do medyków ani do aptek nie było dostępu, zwłaszcza na prowincji, toteż każdy dwór posiadal własną, domową apteczkę i zawiadującą nią osobę. W domu szlacheckim byly dwa rodzaje aptek: dla zdrowia i dla przyjemności (spiżannia). Ochmistrzyni, pani lıb córka ziemianina

...Syreniusza, Marcina z Urzędowa lub inny zielnik przed sobą mając, przewertowawszy go nieraz, umiejąc go prawie na pamięć, gdzie go nie było, z przepisów lub z glowy bieglejsza, od wiosny do późnej jesieni to na alembiku pędzila wody, wódki, smażyła sadla, zbierała thustości, robiła dryjakwie, octy, suszyła kwiaty, liście, owoce, korzenie. Z królestwa zwierzęcego bywały wody i wódki: z piesków młodych, zajączków, królików, bocianów itd., w alembik włożonych i wodą lub wódką nalanych; z roślin, od naszej konwalii zacząwszy i róży, dzięglu, ruty, piołunu, ile ich tylko znać która mogla, lub wyczytać albo zasłyszeć od kogo. Nie zapomniano tu wody marcowej, z śniegu topionej, płeć piękną utrzymującej lub chroniącej od piegów, pierwszej wody deszczowej, albo w czasie grzmotów i piorunów zebranej. Sadła i tłustości, poczynając od ludzkiego, były psie, ze świń, gęsi, niedźwiedzi, borsuków, zajęcy, wilków i lisów. Dryjakwie z wszelkich gadów: żab, węży, jaszczurek, śmiclsze robily w domu, albo sprowadzano weneckie. Octy nade wszystko (...) i zioła wszelkiego rodzaju"'.

W zależności od stanu społecznego kobiety oprócz zajmowania się leczeniem zbierały ziola, handlowaly nimi, stanowiąc konkurencję dla aptekarzy, niosty ponoc tam, gdzie aptek i lekarzy nie było. Na ogól handlem ziołami zajmowały się baby, o których wspomina Marcin z Urzędowa, oskarżają je o oszustwa, a także autor Compendium medicum, który zaskakuje

\footnotetext{
${ }^{* x}$ S. Falimirz, op. cit.. k. 2.

"' Ibidem, s. 30).

") L. Golçbiowski. op. cit., s. 25-26.
} 
niekonsekwentnym podejściem do zielarek. Z jednej strony sugeruje czytelnikom, że mają one sprawdzone, niedostępne zwykłym ludziom środki przeciw chorobom, z drugiej zaś pozwala sobie na drwiny, które przybraly nawet raz formę wierszowanej satyry:

Mają̨ baby leki przedziwne,

Różnym chorobom bardzo przeciwne:

Dziegcie, smalce, woski topione

I różne chwasty z nimi smażone,

Korzenia, zioła, kwiecia prażone,

Kapieli, plastry, trunki warzone

I konfekciki, soki smażone:

Wódki, krystery im doświadczone,

Którymi leczą tak doskonale

Lekarki baby, bardzo zucliwale.

Gdzie się uczyly nauk lekarskich,

Kto ich wyćwiczyl sztuk aptekarskich?

Co baba, doktor; skąd promocyja?

Czy od kądzieli, gdy prządzion zwija?

Nie zna natury ani choroby,

Daje na domysl, doznaje proby.

Wszędy się wrazi, jakby co złego

Uczyć medyka, choćby bieglego.

Racyja za nic medyka stoi,

Baba uporna androny stroi;

Gdy się przylepi szeptem do ucha,

Zwiedziony radą chory jej shucha.

Chociaż przemawia, kryśli i clucha,

Mruczy i żegna, nad głową dmucha,

Nie dba na gusta czlek omamiony,

Że ciężko grzeszy od bab zwiedziony.

Wmawiajz w chorych dziwne choroby:

Suchoty, uraz, wzdęcia wątroby.

Czary, kottony i podwionienia,

I inne różne do podziwienia.

Kry jakieś w bokach, które smaruja,

Trą, rozcierają, one sznurują.

I utrząśnieni zawsze wmawiają

W białą pleć, czym ją oszukiwają,

Na które patrzą, kurzą, smarujaz

I różne plastry jej wynajduja,

Ściągają boki i one prażą.

Aż drugiej oczy na wierzch wyłażą. 
Uroki, glisty w dzieci wmawiają,

$\mathrm{Na}$ nie przemierzłe mikstury dają.

Gdzie bies nie może, tam babę wrazi,

Na każdą sprawę ona narazi.

Jak starym wiechciem dziury zatyka

Babami, gdy ich w każdą rzecz wtyka.

Więc się ich chronić jak ode zlego,

Jak bazyliszka jadowitego.

Abyś dostapil zdrowia milego,

Zażyj medyka rady bieglego.

Nie daj się zwodzić babskiej chytrości,

Przez które szatan wypelnia złości.

Oczyść swe serce grzechem zmazane,

Miej ufność w Bogu, że pożądane

Otrzymasz zdrowie, w ponnocy Jego,

Gdy serce swoje skłonisz do Niego".

Jak wyglądał poziom sztuki tych lekarek bez szkół, czytelniczek poradników, można wnioskować na podstawie dzieł traktıjących o problemach ściśle kobiecych oraz książek napisanych specjalnie dla nich, a także zachowanych źródeł z epoki i wsponnień. Jak napisał Łukasz Golębiowski:

Czy każda rzecz z tych leków pomogła zawsze, nie do nas śledzić należy; wszakże troskliwość ta o zdrowie poddanych i domuwników zaszczyt przynusiła sercui"2.

Z poradników wylania się obraz kobiety in orbe interiori, zmagającej się z codziennością, słabością wlasnego ciala i swoich bliskich, a także wpisıjącej się w zwyczaje, wierzenia i modę. Książki te dają nam jeden z ciekawszych obrazów kobiety tamtych czasów, ponieważ zostaly one potraktowane tutaj jako pehnoprawny odbiorca tekstu, i w związku z tym bardzo rzadko pojawia się w nich negatywnie nacechowany emocjonahny ton (jak w przywołanym wyżej wierszu), który przeważa w wich pismach, zwhaszcza dydaktycznych, skierowanych do kobiet lub o uich traktujących. Tym razem kohiety traktowane są z powaga, podobnie jak ich problemy $z$ whasnym cialem, domem oraz zdrowiem innych.

Z kart poraduików wylania się (charakterystyczny wprawdzie tylko dla pewnej grupy spolecznej - szlachty i bogatego mieszczaństwa) obraz „pani” jako tej, która zarządza domem, jest pełnowartościowym członkiem rodziny, mającym swoje obowiązki, a także decydujący nieraz wplyw na zdrowie ludzi poddanych jej opiece. Rola lekarki i aptekarki sprawia, że wokół niej pojawia się aura tajemnicy, otaczająca kobiety mądre — ,wiedźmy”, przez co zyskuje szacunek należny pierwotnemu znaczeniu słowa: „ta, która wie”.

"Compendium medicum, s. 247.

"Ibidem, s. 26. 
30) Alicja Zdziechiewicz

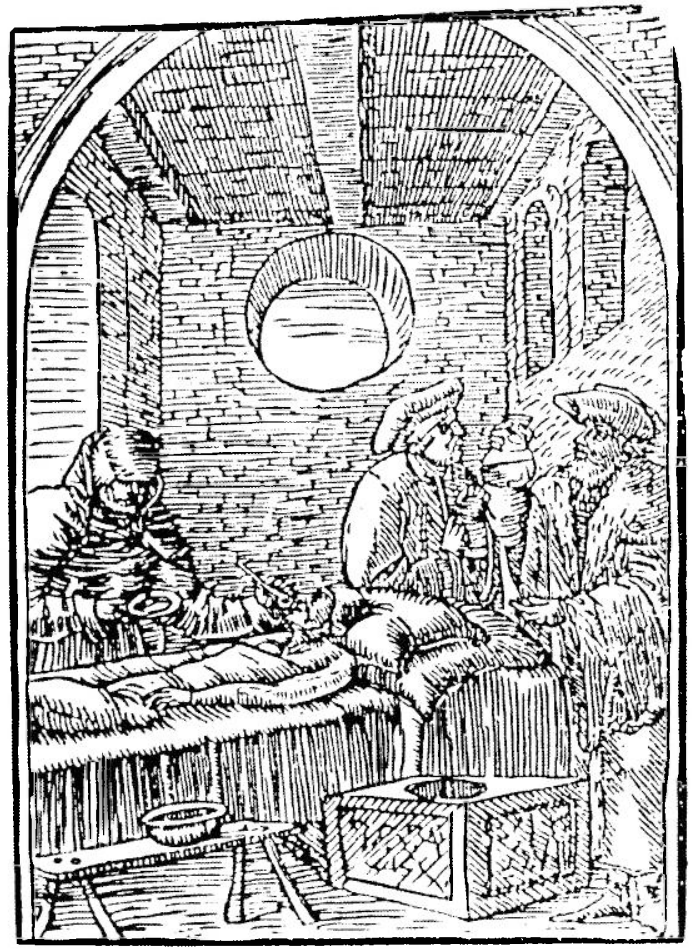

